\title{
Women's Functional Adult Literacy and Access to Community Participation in APAC District, Northern Uganda
}

\section{Judith Abal Akello ${ }^{\text {* }}$ \\ Peace Musiimenta ${ }^{2}$}

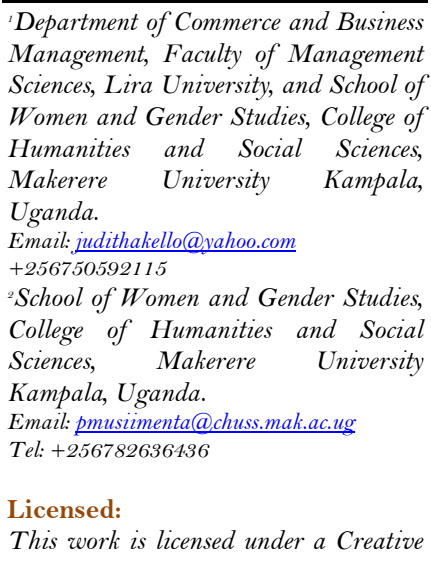

Received: 19 November 2021

Revised: 6 January 2022

Accepted: 21 January 2022

Published: 3 February 2022

(* Corresponding Author)

\begin{abstract}
This article explores how Functional Adult Literacy (FAL) plays or fails to play a role in women's community participation in Apac district, Northern Uganda. The article was underpinned by Freire's literacy and Kabeer's agency theories, which argue that the element of conscientisation enables the marginalised non-literates realise the reality of the world and recognise how it impedes their development. The research on which this article is based employed qualitative case study design to the life changes of 45 participants resulting from their acquired FAL knowledge and skills to participate in community activities and projects. The major findings revealed that FAL training contributes to women having a voice in community meetings and decision-making process and elected or appointed in different leadership positions. The article concludes that given its critical importance, FAL needs to be strongly and consistently supported by the Ministry of Gender, Labour and Social Development (MoGLSD) which coordinates the programme in Uganda as well as other local and international stakeholders. Given that FAL creates consciousness and transforms women's lives to participate within their communities, Civil Society Organisations (CSOs) and development partners should ensure a well-built training programme targeting women for community development purposes.
\end{abstract}

Funding: The research is financed by DAAD (German Academic Exchange Service) (Grant number: 91560790)

Competing Interests: The authors declare that they have no competing interests.

Acknowledgement: The authors would like to thank the German Academic Exchange Service (DAAD) for financial support for research and publication of this article. Further appreciation goes to the District Community Development Office (DCDCO), Apac, for their support and cooperation, which provided us access to the interview sites, as well as to the participants who kindly contributed in interviews conducted for this study.

\section{Background}

Education is a human right that must be accessed throughout life (UNESCO, 2015). The Incheon Declaration $^{1}$, the Sustainable Development Goal (SDG) $4^{2}$ and the Education 2030 Framework for Action ${ }^{3}$ unanimously agreed on the significance of education. They all point to the fact that women, men, girls and

\footnotetext{
${ }^{1}$ UNESCO together with UNICEF, the World Bank, UNFPA, UNDP, UN Women and UNHCR organized the World Education Forum 2015 in Incheon, Republic of Korea, from 19-22 May 2015, hosted by the Republic of Korea. Over 1,600 participants from 160 countries, including over 120 Ministers, heads and members of delegations, heads of agencies and officials of multilateral and bilateral organizations, and representatives of civil society, the teaching profession, youth and the private sector, adopted the Incheon Declaration for Education 2030, which set out a new vision which is an historic commitment to transform lives by all of us through education with bold and innovative actions, to reach our ambitious goal for the next fifteen years (UNESCO, 2015). The Incheon Declaration is significant to any FAL programme in terms of raising awareness and enabling the voices of people, particularly women to be heard in policy development.

${ }^{2}$ This states that it aims to "ensure inclusive and equitable quality education and promote lifelong learning opportunities for all" (UNESCO, 2006a).

3 "Was adopted by 184 UNESCO Member States on 4 November 2015 in Paris. It is the result of a collective effort involving in-depth, wide-ranging consultations driven and owned by countries, and facilitated by UNESCO as well as other partners. The development of the Framework was guided by the Education for All (EFA) Steering Committee convened by UNESCO, and finalised through the Drafting Group for the Education 2030 Framework for Action" (UNESCO, 2015)
} 
boys of all ages must at least possess some basic functional literacy and numeracy proficiency if they are to achieve some level of meaningful individual and communal development. All ages, adults inclusive, should be proficient in literacy and should continue learning through multiple and flexible learning pathways and entry points. Similarly, the policy in Uganda supports and advocates for adult and lifelong learning which are considered to have some bearing on the growth and development of adults (Findsen \& Formosa, 2016).

Since the 1960 s and 1970 s, it has been evident that women compared to men experience lower literacy rate, for example, global and regional trends in the number of non-literates, 1950 to 2000-2004, the percentage of non-literate women has increased from $58 \%$ in 1960 to $64 \%$ today (UNESCO, 2006c). Freire (1970), a literacy scholar has emphasised women's missed opportunities. In particular, Freire pointed out that women who have for long been excluded from attaining formal education have registered very low literacy skills. These are skills that Freire argues could socially transform the unjust power structures through identification of relevant socio-economic issues, analysis and strategising how adult literacy can stimulate socio-economic progress. Women's lack of such literacy skills necessary for economic growth and national development has frequently featured in national and international debates. These debates have indicated that women have subsequently and historically been excluded and increasing their inability to identify obstacles in their social realities which is an obstacle to their development.

Literacy scholars have, therefore, proposed functional literacy as the means for enhancing people's quality and ability to make informed decisions about life. In addition to acquisition of literacy skills of reading, writing and numeracy, many developing countries have adopted the strategy of training nationals in developmentoriented skills and knowledge (Hasaba, 2012; Patel, 2009). A critical analysis of several studies indicates that the provision and accessibility of literacy skills especially by women is a major gateway to social inclusion and sustainable development (Hasaba, 2012; Okech \& Carr-Hill, 2001; Sen, 2003). UNESCO (2006b), which differentiates literacy and functional literacy argues that the former lays emphasis on the utilisation of the acquired literacy skills to change one's life while a literate person is measured by his or her ability to read and write (MoGLSD, 2007).

Besides, Functional Adult Literacy (FAL) has its origin in the perceived role of literacy in empowering learners (Patel, 2009). Furthermore, in 1960s and 1970s, UNESCO introduced Experimental World Literacy Programme (EWLP). The EWLP perceived education as a key input for development and advocated for human capital models of education. The EWLP projected that literacy must go beyond the process of learning the skills of reading, writing and arithmetic, and contribute to the 'liberation of people' and to their full development (Stromquist, 2005; UNESCO, 2006a). Freire's influence on both declaration and programme emphasised that the acquisition of literacy skills of reading, writing and arithmetic should not be an end in itself but a means to an improved learner's critical consciousness of his/her social reality. Literacy should enable the learner's engagement on praxis, or, a "reflection and action upon the world in order to transform it" (Freire, 1970). Freire, further maintains that the aim of a functional literacy program is not only to help learners to acquire literacy skills but also to learn. For example, a learner should learn skills such as economic, social and political skills which will empower him/her to cope better in society. Till 1973, the UNESCO Experimental World Literacy Programme (EWLP), also supported by the United Nations Development (UNDP) and other international agencies were implemented in eleven countries 4 .

In Uganda, the government first launched the UNESCO's EWLP in 1964 with a primary reader and a text for additional reading, available in twenty-two languages. Originally, the EWLP programme targeted young and old men and women, girls and boys that had never attended formal education during childhood. The focus was later shifted to include specific groups of marginalised people such as prison inmates, the disabled and ethnic minorities above the age of fifteen (UNESCO, 1974). However, this change failed because the required adaptations could not easily be grafted onto existing materials published in 1964 (UNESCO, 2008). A report from UNESCO further revealed that, implementation of FAL completely lost steam during Idi Amin's regime as president due to very little government provision for adult education.

Between 1983 and 1989, UNESCO once again spearheaded the revamping of FAL training in Uganda. By early 1990s, the Government of Uganda was co-financing the UNESCO led FAL programmes (Hasaba, 2012; Okech \& Carr-Hill, 2001). The Ugandan Government amended the FAL training curriculum into what became popularly known as the Integrated Non-Formal Basic Education Pilot Project (INFOBEPP). This was implemented in 8 districts, including: Apac, Hoima, Kabarole, Mbarara, Mukono, Mpigi, Kamuli and Iganga (Nsekaki, n.d). Early assessments of INFOBEPP noted high levels of eagerness and enthusiasm amongst communities where it was tested. Numerous classes started outside the pilot area. In 1997 the government of Uganda turned INFOBEPP into the official national FAL programme, which was to be implemented across the country with some assistance from NGOs ${ }^{5}$. Hence, FAL programme was designed to incorporate a rich skill-specific training, in addition to reading, writing and numeracy, and showing learners how FAL can be used for personal development in their everyday lives.

\footnotetext{
${ }^{4}$ Algeria, Ecuador, Ethiopia, Guinea, India, Iran, Madagascar, Mali, Sudan, Syria and Tanzania (Bataille, 2016).

${ }^{5}$ These included: Action-aid, National Adult Education Association, and Uganda Community Association for Child Welfare, Uganda Joint Action for Adult Education, Religious bodies and some parastatal organisations.
} 
Globally, adult literacy stands at $89 \%$ for men and $81 \%$ for women, with a total number of non-literate adults at 757 million. Out of the total non-literate adults, $63 \%$ of the non-literate population are women (UIS, 2015; Vágvölgyi, Coldea, Dresler, Schrader, \& Nuerk, 2016). UNESCO’s report indicates that, two of three equal parts of the non-literate population are women who lack the basic skills of reading, writing and numeracy. In sub-Saharan Africa, a comparison between neighbouring countries show that Uganda has registered lower literacy rate and the majority of the non-literate population are women. The literacy rate in Kenya is at $91 \%$ for men and $84 \%$ for women (UNESCO, 2013). Likewise, in Tanzania, UNESCO (2016) report indicate that the literacy rate for men stands at $84.1 \%$ and $74.4 \%$ for women. In Uganda, the literacy rate for rural-based females is at $68 \%$ and men's literacy in the same area stands at $77 \%$ (UBOS, 2016). However, the rural-based female literacy rates are much lower than those of urban-based males, which are reported to be $83.6 \%$ for females and $88.7 \%$ for males (UBOS, 2016). Generally, women in developing countries have experienced lower educational attainment than men in addition to other forms of gender inequalities they experience. It is not surprising therefore, that women form the poorest, under-employed and un-employed segment of most communities (Kabeta \& Gebremeskel, 2013; Nudzor, 2015; Stromquist, 2016; Wong, 2012).

Stromquist (2016) and Bishaw (2014) have shown that lack of literacy skills prevents many women from fully realising their rights, becoming more involved in community activities and contributing to socioeconomic development in their community. Therefore, this article focuses on how acquired literacy skills have enhanced women's capability to participate in their communities. It emphases on women having a voice, particularly, in community meetings, decision making process and participating as leaders in community development projects and improving their lives.

\subsection{Theoretical Framework}

This article is theoretically grounded within the arguments of agency theory traced right back to Freire's literacy theory and Kabeer's agency theory of development. The choice of agency is influenced by theoretical focus on placing women's capability and active participation in a prominent position if their status and lives are to be transformed.

\subsection{Agency Theory from Kabeer's Socio-Economic Perspective}

Kabeer argues that agency is a person's ability to define his/her strategic life choices and act upon them despite the prevailing opposition from others (Kabeer, 2005). Kabeer's argument is critical in this study because it holds that women should engage in transformative development as active agents not passive participants. However, this explanation takes note of how various societal institutional biases, customary, cultural and ideological norms and values restrict many women's ability to make such choices. Such an argument pushes for a need to strategically bridge the gender gap at the levels of both formal and informal institutions through a joint intellectual model. Bridging such gender gap requires changes that serve women's strategic gender interests, for example, reducing discriminatory gender division of labour and unequal control over resources.

Understanding agency which Kabeer (2005) explains as both "passive" and "active" helps identify how literacy skills enable women to change their lives. Passive agency is "action taken when there is little choice" while active agency is "purposeful behaviour". Hence, the conception of active agency suggests that FAL trained women are expected to become active agents of their socio-economic development. Kabeer's perspective of agency theory is one lens through which women's efforts or a lack of any effort to utilise FAL skills acquired to effect socio change in their lives is examined in this study.

From a socio-economic development context, Kabeer (2005) emphasises the power of education and literacy to ignite women's agency and social inclusion. This implies that literate women must have the agency to question, analyse and challenge the patriarchal structures that reproduce constraints and inequalities in their lives. Like Kabeer (1999) argues that a good basic training can improve the capability of a person to earn more and improve their well-being. Sen maintains that women's well-being comes through agency. Both Sen and Kabeer therefore indicate that depriving women of well-being is a matter of social injustice for them, but which is also likely to affect their capability to develop their societies.

Focusing on the agency theory argument is paramount because it explains women's active involvement in community and participation in development which is significant to this study. Participation in this framework must be distinguished from mere involvement; rather, it should be considered as an inclusive process in which stakeholders are involved in, and, more importantly, have some level of control over decisions that affect them (Stewart \& Sinclair, 2007). Stewart and Sinclair's views rest on the assumption that development is about people becoming agents in development. This argument helps to understand that rather than merely consulting people especially women and providing input, they should be capacitated to participate in decisions that affect them. Both Sen (1999) and Kabeer (2005) point to the linkage between women's capability and socio inclusion and emphasise the impact and the part played by, for instance, education and literacy skills acquired. A critical analysis of duo's views depicts literacy skills as crucial determinants of women's agency and inclusion in community activities. For example, Sen's arguments clearly indicate that women who have acquired literacy skills can take part in their children's survival, reduction in fertility and health, generating 
income and improving their individual and family well-being. This argument presents agency as an enabling factor to literate women's voice in discussing issues in and outside family (Sen, 1999). Agency theory therefore, was suitable in informing a study reviewing how women FAL beneficiaries of a participatory development perspective became or failed to become agents of their social development. Positively, literacy skills strongly contribute to women's agency to community participation and development.

\subsection{Agency Theory from Freirean Literacy Perspective}

Freire's literacy theory is founded on notions of social inclusion and agency. In the acquisition of education, Freire emphasises conscientisation, which is a deliberate effort of a teacher to open the minds of the learners to discover the world within which they live. The notion conscientisation is the process where people are made aware of and understand their surroundings and the overriding socio-economic structures (Freire, 1970; Kotsapas, 2010). Freire's literacy theory was found relevant in this study. For example, the conscientisation process enabled the participants to identify socio- structures, such as, patriarchy that oppresses and marginalise them.

Freire's pedagogical approaches on adult literacy seem more transformative. For example, if contextually adapted methodologies, such as, problem-posing education or training which can contribute to the identification and analysis of pertinent socio-economic issues that affect adult literacy training. Subsequently, this can contribute to changing societal unjust power structures, hence, promote socio-economic progress. This aligns with what (Freire \& Macedo, 1987) explains that lack of consciousness of the real world, limited social awareness and critical inquiry limit social change especially to the non-literate women. From Freire's argument, literacy should not only impart the skills to read, write and do arithmetic, but also contribute to effective functioning and development of an individual, a group and the community (UNESCO, 2006). Hence, for women who have acquired the literacy skills should translate them into practical benefits. They should for example act as functioning members in their families and community, as demonstrated by their strengthened awareness and agency to participate in male dominated community. Freire's perspective on critical consciousness, promises enjoyment of freedom to the oppressed, marginalised and socially excluded people, especially the women-freedom to participate in development, for example, in public dialogue, education or training and health care facilities (Freire, 1970; Sen, 1999).

\subsection{Literacy Training and Women's Community Participation: A Review of the Literature}

Studies show that literacy training is critical to community participation. UNESCO (2006) has elaborately explained the major benefits of literacy in society, such as, building a person's confidence and self-esteem; wiping away ignorance; political apathy and encouraging mutual understanding and cooperation among the various strata of society. This creates an impression that for individuals to fit comfortably in a community and participate in its activities, they must be literate.

A study by Olomukoro and Adelore (2015) found that there is a strong relationship between literacy and community participation. They reported that in Nigerian states of EDO and Delta, women participants became leaders of their different groups; $91 \%$ had their opportunities enhanced for leadership positions in their various organisations; $79 \%$ participated in local meetings, while $88 \%$ confirmed that literacy skills prepared them for leadership roles in the society. While there could have been other factors, the study shows that literacy played a significant role in enabling women to actively participate in the leadership positions of their communities.

The above views corroborate the earlier studies which indicated that literate women in Nigeria and $\mathrm{El}$ Salvador confidently claimed their voice to participate in community meetings compared to their non-literate counterparts (UNESCO, 2006a). These studies revealed that literacy training equipped the women with an opportunity to develop new perceptions, knowledge and experiences as well as ability to support one another for their social progress. These diverse views seem to unanimously agree that adult literacy programmes correlated significantly with women leadership role in the society.

A study in Nepal compared the lives of FAL-trained women with their non-literate counter-parts in relation to their community participation. It was found that those across all levels in literacy programmes participated more than those outside the literacy programme (Murtala, 2013). In her argument, Murtala showed that non-literate women have low self-esteem which consequently limits their effective integration into various development processes (Murtala, 2013). In a related study, Stromquist (2009) revealed that, women in Nepal who had participated at least two years in a literacy programme had clear benefits compared to non-literate participants. For instance, the literate women easily became members of a community group, participated more in community decisions and quickly gained awareness regarding sex trafficking of girls and domestic violence. The above studies resonate (Freire, 1970) argument that skills acquired from education serve as a form of liberation. Such skills enable the learner to take necessary action to challenge and change obstacles to her/his development. Other studies have approached the benefits from capability and freedom perspective. Sen (1999); Nussbaum (2001) and Freire (1970) argue that once skills are acquired, capability or ability to act and freedom to participate in the community activities, it is likely that these can change women's lives. These might be socio-economic changes that can impact women as individuals or even their families or communities. 
The above arguments should however be taken cautiously and contextually. A study in the Nigerian state of Ebonyi on functional impacts on adult literacy programme among rural women indicated that participants witnessed less benefits (Ayodele \& Adedokun, 2012). It was found that literacy programme offered to the rural women did not help them to participate in maintaining peace in their various communities. While the study attributed this scenario to community chaos resulting from land dispute, community clashes and killings, there could be other factors in other communities. Therefore, for Literacy programme to be beneficial, there must be an enabling environment for women to translate their level of reading, writing and numeracy into effective participation in their community (Ayodele \& Adedokun, 2012). Bari (2005) defined an enabling environment as a set of related and interdependent organised settings, for instance, policies, institutional mechanisms and resources that enable the promotion of good gender relations. Ayodele's argument indicates that, achievement of literacy level alone is not a guarantee for participation in development. There must be harmony as the core since no significant community development project can be carried out in a chaotic community. Nevertheless, Kabeer (2005) and Sen (1999) maintain that literacy skills acquired are crucial determinants of women's agency and social inclusion as well as ability to participate in community undertakings. Drawing on Kabeer and Sen's perspective, a low level of literacy impedes women's abilities to skilfully question, analyse and challenge the patriarchal structures that exclude them from participating in community undertakings.

\subsection{The Gaps in Literature}

A review of the above literature on women and FAL training indicates that most literature focuses on women's ability to reading, writing and basic numeracy. Notably, women's ability to benefit from literacy programmes are context specific and this should be flagged out clearly by studies. There has been insufficient information specifically on how FAL training in Apac District have enhanced their capability in community participation. The fact that this study is carried out in Apac District is in the right direction towards filling the gap in literature as well as creating an avenue to report on how literate women are socially included or include themselves due to capability and high self-esteem to participate in community activities.

\subsection{Methodological Process}

Using the qualitative interpretive framework, the study investigated the phenomenon of how FAL strengthen women's agency to participate in the socially constructed male dominated community. Following a case study research design, the researcher explored women's experiences as beneficiaries of the different levels of FAL programme in the Ugandan district of Apac.

Whereas the study focused on FAL women beneficiaries' experiences, the researcher purposely selected few men as witnesses of what FAL had done to the women in their lives. To capture their views, we had an indepth interview and Focused Group Discussions (FGDs) with few men- family members or those that had close relations with the women participants or had the knowledge of FAL training programme. The purpose for men's inclusion was to get testimonies from 'outsiders' but in the communities where women FAL beneficiaries live. It was also important to capture contrasting perceptions on FAL training programme. In addition, majority of the women we talked to suggested that the discussion should include men as indicated in Table 1 below. Forty-five participants were purposively selected and deemed adequate to qualitatively enable in-depth data collection analysis (Creswell, 2011). The key criteria for selecting participants was one's literate and non-literate status. The literate participants comprised of those that had graduated in the training during the period 2011-2013. The choice of this period was for the purposes of getting up to date information about women's experiences in FAL training in relation to socio-economic progress. Moreover, participants that enrolled in 2014 had not yet completed their three levels of training. In addition, key informants including District Community Development Officer (CDO) and Assistant Community Development Officers (ACDOs) were selected and interviewed because of their knowledge and experience regarding the study topic. For example, the District Community Development Officer (DCDO) represented the government institution, that is, MoGLSD which coordinates FAL programme at national level.

Table 1. Distribution of study participants-in-depth and key informant interviews and FGDs.

\begin{tabular}{l|c|c|c|c|c|c}
\hline \multirow{2}{*}{ Study Site } & \multicolumn{2}{|c|}{ In-depth-Interview } & Key Informants & \multicolumn{2}{c}{ FGD } \\
\cline { 2 - 7 } & Women & Men & Women & Men & Women & Men \\
\hline Apac Town Council-Apac District & 22 & 2 & 0 & 1 & 10 & 2 \\
\hline Chawente Sub-County, Apac District & 3 & 1 & 1 & 0 & 0 & 0 \\
\hline Inomo Sub-County, Apac District & 7 & 5 & 0 & 1 & 6 & 3 \\
\hline Total & 32 & 8 & 1 & 2 & 16 & 5 \\
\hline
\end{tabular}

Three qualitative methods of data collection used were: in-depth interviews, FGDs and observations. Key informant interviews were conducted with technically informed individuals to share their knowledge and experiences on how FAL plays a role for the enhancement of women's participation in community activities and development of the Northern Uganda district of Apac. Triangulation of methods enabled the researcher validate data collected using one method with another which boosted the richness of data collected. A face-toface interview using an in-depth interview guide was conducted with the participants to capture their views on 
the benefits or challenges involved in or not participating in FAL, while FGDs were conducted and provided an opportunity for open discussion on women's experiences on FAL. FGDs shared information on women's improved capability to participate in community projects due to their acquired skills from FAL programmes. Direct observations of the participants helped the researcher to understand the meaning of participants' experiences and interpreting the non-verbal responses.

Secondary data collection also provided another source of important information. The relevant literature was sought especially from books, journals, unpublished academic reports such as theses and published materials gathered online and university libraries, documents from the District Community Development office and Sub-county offices where the study was carried out.

Data analysis was guided by Creswell (2007) recommendation which includes: data management phase, generative phase, interpretive phase, and representing and theorising phase. Primary data was analysed using themes in which the textual data and observations were noted immediately when data collection started. Relevant literature from secondary sources was reviewed to supplement primary data. During the generative and interpretive phase, qualitative data was coded using qualitative content analysis for key informant and indepth interviews, while reading the whole transcripts numerous times to get logic in relation to the specific research questions and the study objective. The researcher eventually identified the key words and later developed categories and themes generated from the participants' responses. The themes emerged from data as the in-depth interview progressed. The data generated two themes, which includes: Women's claimed voice in community meetings and decision-making process; and women's claimed participation in leadership.

The data collection process entailed organising and interpreting data for meaning making out of the data through identification of themes, patterns and explanations.

\section{Limitations}

The first challenge was communication gap. Most of the participants in the rural areas did not keep their phones on due to limited access to phone battery services. Whenever, I made an appointment with the participants and would want to confirm by making a follow up on the appointment date, I would find most of their phones off and they would give the reasons that, since, no one calls them, there was no reason leaving it on. After all, they already knew the date I was scheduled to meet them. While to them it was not an issue, it made my fieldwork a bit challenging, although I always just went to the participants on the agreed dates.

\section{Findings and Discussion}

Findings are presented and discussed concurrently under the following sections: women's claimed voice in community meetings and decision-making process, women's claimed leadership and participation

\subsection{FAL training and Opportunity of Women's Community Participation}

Findings show that FAL is critical in the changing women's lives. Women identified FAL to contribute greatly in strengthening their ability to participate in socially constructed male dominated community. During interviews, women interpreted their coming together as crucial as it enables them not only to meet, but also to ably plan and share significant ideas. To the women beneficiaries of FAL, through such meetings and shared ideas or knowledge enables them to actively participate in their communities for socio-economic development. This finding tally with Prah (2013) argument that "it is only when people meet that they are able to discuss, make plans and come out with important ideas which would help them and their communities to develop".

Notably, most patriarchal societies, restrict women's mobility which in turn limits their community involvement. In Apac district like most parts of Uganda, patriarchal restrictions limit women's movements and probably this explains their low levels of literacy. Patriarchy therefore formed a serious obstacle to nonliterate women's involvement in community activities. Most women perceived FAL to as a key that unlocked them to actively exercise their agency as illustrated by Lillian's shared experience that:

Before we enrolled for FAL, we the women were not allowed to do any work or participate in any activity or even business. Men would say, traditionally, the work of women is to stay and keep the home. They are to be as padlocks in the home.

The above quote clearly depicts FAL as an important opener of a new window into a new world. We search how literacy skills enable women's participation in their communities, we particularly focus on women's claimed voices in community meetings including the process of decision making and concurrently playing leadership roles in community development projects. Women's claimed voice means that FAL skills contribute to improving their ability to discuss issues that affect their participation in community activities.

\subsection{Women's Claimed Voice: Community Participation, Meetings and Decision-Making.}

From the women's perspective, FAL training has not only been a learning programme where women received knowledge and skills, but also a social space where they meet to discuss issues that affect them and their community. The women we talked to, underlined the importance of the knowledge acquired from FAL. They argued that it leads to increased women's participation in community meetings as well as amplifying their voice on issues of developmental nature. One of the participants of FAL Ayuru expressed her experience 
as a beneficiary of FAL. With excitement, she revealed how participating in FAL programme enabled and added value to her which in turn contributed to her participating in community meetings:

FAL has recognised gender equality whereby women that are literate are now made to participate equally in decision making during consultative meetings. For instance, I have seen where water user committees in our villages, literate women have been elected to be in the committee and their decisions are respected during meetings.

Ayuru's expression was validated by men who said that FAL enhances women's capability. According to Adonga's opinion, one of the male FAL participants, women who complete FAL training are valued and more likely to be listened to in their communities. There is a common belief that the literate members of the communities are more knowledgeable in terms of current social issues. Accordingly, the voice of the literate persons is valued. When the literate speaks during a misunderstandings and conflict resolution, they are likely to be taken more seriously. Adonga shared his opinion by stating that:

Because of FAL, I have learnt how to cooperate and share with people in the community to avoid misunderstanding. I had little knowledge before FAL. Also, no one would listen to me during meetings when I was non-literate. People would tell me that I know nothing, and I do not understand anything. Now, I have the skills. To me, where there is peace, there is also teamwork, and this promotes social progress of the community.

The above quote seems to portray the non-literate as less knowledgeable. However, this is a misconception because even the non-literate men and women have indigenous knowledge which participants in this study seemed to take for granted. In most discussions even, women themselves depicted the nonliterate as less 'knowers' and the literate as 'knowers' or those who crossed to the space of 'knowers', a divide that can easily create a misconception that the non-literate don't know. This is not to devalue the benefits of FAL but to guard against portraying the non-literate as those who don't know.

FAL was also found to increase women's confidence and ability to discuss issues that affect their lives in community meetings. The beneficiaries' as well as FAL coordinators appreciated and acknowledged FAL programmes' benefits to women, such as, contribution to their ability to participate in community activities. One of the Key Informants attributed women's contributions in community meetings to FAL training arguing that women who attended FAL were likely to confidently express themselves during community meetings. He further recalled some of women's expressed confidence as he mentioned:

We have always held meetings on household sanitation, hygiene, gender issues and planning. This has made us to observe the good things that FAL has done in terms of improving women's lives because they can now speak on issues concerning women. However, those who are untrained and have not attended FAL training shy away from participating in community activities.

The above Key Informant's expression that "they can now speak on issues concerning women", implies that individual women acknowledged how FAL strengthened their public speaking skills and confidence. Accordingly, women's confidence was attributed to their continuous experience of speaking before their fellow FAL learners during the training which built their capacity. Thus, women's FAL skills influence their ability in discussing openly issues affecting their lives and this indicates what (Kabeer, 2005) terms 'active agency'. Active agency means that women who are literate also have a role to play in strengthening their agency through FAL in the socially constructed male dominated space.

Some individual women validated what the Key informant said about FAL improving the lives of beneficiaries. Adule, 74 years, and now a Catechist after FAL training agreed with the Key Informant's point of view that, "FAL has empowered me socially. I can now express myself freely without fear. I have also attained confidence and courage where I stand in public and advise where necessary compared to when I was untrained". From Adule's articulation, ability to 'stand in public' and give advice is a way of expressing the social inclusion by the literate participants and the difficulties the non-literate people face in the community.

Summing up the views from both the individual women's experiences and the key informants, FAL training is therefore a tool for accessing information, knowledge and skills, FAL creates awareness, understanding and power, for multiple purposes. Literacy learning, as Freire suggests, is very important to making sense, not only of the word, but also of the world (Freire \& Macedo, 1987).

Comparatively, FAL changes the lives of those who train and those who miss out. The non-literate participants shared their experiences on how lack of training has disadvantaged them by lowering their selfesteem and confidence both at family and community level. Women who did not get an opportunity to patriciate in FAL, felt cheated, and left out because FAL was portrayed as a compensation for the lost formal educational opportunities. Nansier, a 44-year-old woman and a non- FAL trained participant expressed contentments:

Now that I don't know how to read and write, it has made me to be so much behind. Whenever we are in a meeting and so many people are raising their views, sometimes I feel like raising or complimenting an issue, but due to fear and low self-esteem, I shy away.

Nansier's revelations about how non-literacy disadvantages women has constrained her compared to literate group of women. Implicitly, she revealed out that being literate increases women's community participation compared to non-literate women. Such participation is not only linked to their non-literacy status 
but also due to cultural attitudes to women. Thus, changing women's lives through FAL is only one of the gateways to improving their social status.

\subsection{Women's Claimed Participation in Leadership}

In addition to claiming a voice in community meetings and decision-making process, most women that acquired FAL skills were found to be elected or appointed in different leadership positions. The various community activities where FAL women beneficiaries excelled include distribution of essential drugs, HIV/AIDS sensitisation, overseeing health and hygiene in the homes and spraying mosquitoes. Filomena, a 74-year woman and a farmer, explained how FAL skills have capacitated her to participate in community activities as a member and leader. She explained that:

Because of FAL, I am now a member of Village Health Team. I distribute tablets to the community, sensitise the community on voluntary HIV/AIDS testing. I oversee sanitation by checking whether the toilets are kept clean, whether they are drinking clean water. I also sensitise the community on having racks at home, a wire for hanging clothes to avoid getting infected with skin diseases, that children between 0-5 years are immunized and that there should be a house for animals, chicken, bathroom and rubbish pit.

Filomena's foregoing discussion on her improved capability in community participation, with the statement "Because of FAL, I am now a member of Village Health Team" implies that literate women have a high self-esteem which makes them easily integrated in the process of community activities. According to one FAL coordinator and Key Informant, FAL training had changed the lives of many women and their families. For example, the FAL Coordinator was quoted saying that "there is one of the FAL participants who was very unhygienic before FAL training, but now she is much respected in the community, her home is very clean and she participates in spraying mosquitoes". The above findings corrobate with Nussbaum (1999) and Freire (1970) viewpoint which established that, building women's capabilities by, for example, providing adequate training serve as a form of liberation by creating awareness, opportunities and changes in their social lives in a community.

In addition to participating in community undertakings, findings further, show that FAL trained women had the capacity to be elected in leadership positions in their communities. Findings from Magdallene, a 64year-old woman also lends support to the claim that FAL skills enabled women to participate in community undertakings compared to non-literate women. She narrated that:

Due to FAL skills acquired, I teach members of the community especially the women on how to keep their homes clean. I also sensitise the youth, especially the young girls on the dangers of HIV/AIDS and how to protect them from being infected. In leadership, I hold three posts. I am a sub-county Councillor, a borehole care taker and finally, a traditional birth attendant.

A critical analysis of the above voices indicates improvement in women's lives. Women that participated in literacy training became members of a community group, had increased participation in community decisions, and gained awareness social issues affecting them. It also clearly demonstrates that FAL skills have transformed women that missed the opportunity in formal education into leaders in their community. Similarly, UNESCO's report on Uganda traced back women's increased involvement in local governance and decision making, community sanitation, and agricultural and nutritional improvement to FAL training (UNESCO, 2008). Filomena, a 74- year woman FAL graduate, attributed that FAL skills enhance women's ability to share leadership roles and responsibilities in the community. She narrated her life experience and how the community considers her as a potential leader and role model where she lives and her ability to share community roles and responsibilities. She explained:

After the FAL training, I have been elected as a member of Parish Development Committee (PDC). The roles include, sitting in a meeting and gathering all the problems of each village which includes, lack of clean water, access roads and sometimes emergency of an outbreak of a disease like cholera. Then later we meet in the parish and analyse the problems that are urgent with Local Council leaders of all the villages.

Like Filomena, Nampa, a 50-year woman and FAL participant displayed her positive experiences of FAL:

Right now, as I speak, I am the secretary women's council I at the parish level and a secretary women's league in one of the political parties. They elected me because they knew I know how to read and write and I can manage the post. Members would not have elected me if I did not know how to read and write.

Some women perceived Corina, a 43-year-old woman, a FAL- trained woman also supplemented Filomena's experience how the capability to reading and writing has transformed her into leadership in the community. She said:

Whenever, there is an election, I am always selected because of the skills in reading and writing. I was elected as a chairperson of borehole water project because I could stand, talk and give opinion and people also came to entrust me with responsibilities.

Filomena, Nampa and Corina's voices clearly demonstrates an opportunity for women in leadership positions in their various groups in the community. This corroborate (Olomukoro \& Adelore, 2015) findings that literacy skills prepared women participants in EDO and Delta States, Nigeria for leadership roles and majority of them had their opportunities enhanced for leadership positions in their various organisations in the society. 
Comparatively, women's voices were supported by the voice to a man who explained that non-literacy is a serious impediment that prevents women involving more in community activities. Okello, now, FAL graduate and a community leader in his mid-eighties explained that:

Being unable to read or write makes me to have very low self-esteem. I wanted to be elected as a secretary in the Local Council (LC) I leadership, but I was left out because I am non-literate. Above all my colleagues that participated in FAL training, I have seen they have self-esteem where they can express themselves in public. Reading and writing skills have made them to be elected in various positions in the society, that is, LC I level and secretary of an association.

Okello's proclamation that, "I wanted to be elected as a secretary in the local council I leadership, but I was left out because I am non-literate" indicates that non-literate women miss the opportunity for being integrated into the lowest political administrative in a village of community, comprising of, for example, 60 households. The above findings tally with previous studies that women across all levels in literacy programme participated more in community groups than those not in a literacy programme (Murtala, 2013). Many voices to women concluded that their intelligence from the skills acquired from FAL training has promoted their participation in community activities and development projects. Filomena acknowledged that, "FAL training has given me knowledge, where I can now differentiate between what is good and bad. Some of us here are leaders in various capacities finance secretary and overseeing local security".

\section{Conclusion}

This article revealed that FAL training did not only provide knowledge and skills, but also a social space where women could meet to discuss issues that affect them and their community. For example, women in Apac became members or leaders of a community group member of Village Health Team (VHTs) or secretary women's council, had increased participation in community decisions, and gained awareness social issues affecting them. Also, by women having a voice and making decisions on issues that affect their lives after acquiring FAL skills clearly demonstrates that FAL skills have improved women that missed the opportunity in formal education into leaders in their community. Women's acquisition of FAL skills is an attempt in the right direction to transforming the strong socio-economic structures that exclude women from participating in the family or community activities.

\section{Recommendations}

There is need for a strong and continuous support of FAL programme by the MGLSD which coordinates FAL programme in Uganda. Other stakeholders such as the international development partners and the Civil Society Organisations should buttress the MoGLSD to create a conducive environment for the FAL programmes sustainability.

The civil society and policymakers at the central and local government levels should formulate supportive gender responsive policies and legislations and put mechanisms in place to ensure implementation is done.

Since scholarship and government reports in Uganda indicate that many women are still non-literate compared to men, inclusion of adults that missed formal education must start with policy review and action plan on compulsory FAL training particularly for the women.

To ensure significance of educating women and their visibility in the community, this study recommends the creation of awareness by all concerned bodies, that is, MoGLSD, international development partners, NGO's and civil society. For example, non-literate women and the community should be sensitised on both the visible and invisible benefits of acquiring FAL skills to attract and encourage mainly women that have missed the opportunity of formal education.

\section{References}

Ayodele, J. B., \& Adedokun, M. O. (2012). Towards achieving functional adult literacy in Nigeria. European Scientific Journal, 8(5), 209-2 18.

Bari, F. (2005). United nations division for the advancement of women (DAW) expert group meeting enhancing participation of women in development through an enabling environment for achieving gender equality and the advancement of women Bangkok, Thailand. Retrieved from: https://www.un.org/womenwatch/daw/egm/enabling-environment2005/docs/EGM-WPD-EE-2005EP. $12 \% 20 \% 20$ draft $\% 20$ F.pdf.

Bataille, L. (2016). A turning point for literacy: Adult education for development the spirit and declaration of persepolis: Elsevier.

Bishaw, A. (2014). The impact of education on rural womens participation in political and economic activities. International Journal of Educational Administration and Policy Studies, 6(2), 23-31.Available at: https://doi.org/10.5897/ijeaps2013.0316.

Creswell, J. W. (2007). Qualitative inquiry and research method: Choosing among five approaches (2nd ed.). Thousand Oaks, CA: Sage

Creswell, J. W. (2011). Educational research: Planning, conducting, and evaluating quantitative and qualitative research (4th ed.): Pearson.

Findsen, B., \& Formosa, M. (2016). International perspectives on older adult education. Hamilton, New Zealand: Springer.

Freire, P. (1970). Pedagogy of the Oppressed, trans. Myra Bergman Ramos. New York: Continuum.

Freire, P., \& Macedo, D. (1987). Literacy: Reading the word and the world. Great Britain: Routledge. 
Hasaba, S. (2012). Education for all: Reflecting on adult literacy learning for socio-economic development in Uganda. Academic Research International, 2(2), 205-216.

Kabeer, N. (1999). Resources, agency, achievements: Reflections on the measurement of women's empowerment. Development and Change, 30(3), 435-464.Available at: https://doi.org/10.1111/1467-7660.00125.

Kabeer, N. (2005). Gender equality and women's empowerment: A critical analysis of the third millennium development goal 1. Gender \& Development, 13(1), 13-24.

Kabeta, G. G., \& Gebremeskel, H. H. (2013). Impact of gender roles on women involvement in functional adult literacy in Ethiopia: A review. The International Journal of Social Sciences, 9(1), 37-54.

Kotsapas, A. (2010). Adult literacy and women's empowerment: Exploring the contribution of a non-formal adult literacy programme to women's empowerment in Aileu. Timor Leste: A Thesis Presented in Partial Fulfilment of the Requirements for the Degree of Master of Philosophy in Development Studies at Massey University, Albany, Manawatu [ie Manawatu], New Zealand.

MoGLSD. (2007). Strengthening literacy practises in uganda through funtional adult literacy education. Kampala,Uganda: MoGLSD.

Murtala, A. Y. (2013). Impact of adult literacy programmes on political empowerment of women in Kwara State. International Journal of African and Asian Studies, 2, 17-22.

Nsekaki, P. (n.d). Functional adult literacy programme (FAL). Retrieved from: http://www.natcomreport.com/uganda4/livre/functional.html.

Nudzor, H. P. (2015). Taking education for all goals in sub-Saharan Africa to task: What's the story so far and what is needed now? Management in Education, 29(3), 105-111.Available at: https://doi.org/10.1177/0892020615584105.

Nussbaum, M. C. (1999). Sex and social justice: Oxford University Press.

Nussbaum, M. C. (2001). Women and human development: The capabilities approach (Vol. 3). United Kingdom: Cambridge University Press.

Okech, A., \& Carr-Hill, R. A. (2001). Adult literacy programs in Uganda. United States of America: World Bank Publications.

Olomukoro, C. O., \& Adelore, O. O. (2015). Political empowerment of women through literacy education programmes in EDO and Delta States, Nigeria. Journal of Adult and Continuing Education, 21(2), 3-23.

Patel, I. (2009). Policy on adult and lifelong learning: International and national perspectives participatory lifelong learning and information and communication technologies (PALDIN), course (Vol. 1): UNESCO.

Prah, M. (2013). Insights into gender equity, equality and power relations in Sub-Saharan Africa. Uganda: Fountain Publishers.

Sen, A. (1999). Development as freedom. New York: Anchor Books.

Sen, A. (2003). Reflections on literacy Literacy as freedom (pp. 20-30). Paris: UNESCO.

Stewart, J. M., \& Sinclair, A. J. (2007). Meaningful public participation in environmental assessment: Perspectives from Canadian participants, proponents, and government. Journal of Environmental Assessment Policy and Management, 9(2), 161-183.

Stromquist, N. (2005). The political benefits of adult literacy. Background paper for the education for all global monitoring report 2006: literacy for life. France: UNESCO.

Stromquist, N. P. (2009). Literacy and empowerment: A contribution to the debate. Background study commissioned in the framework of the United Nations literacy decade. Paris: UNESCO.

Stromquist, N. (2016). Adult literacy and women: A present account. Dialogues in Social Justice: An Adult Education Journal, $1(1), 18-22$.

UBOS. (2016). Uganda Bureau of Statistics 2016, The national population and housing census 2014 - Main Report, Kampala, Uganda Kampala, Uganda.

UIS. (2015). Adult and youth literacy unesco institute for statistics, Retrieved from; http://www.uis.unesco.org/literacy/Documents/fs32-2015-literacy.pdf.

UNESCO. (1974). The experimental world literacy programme and its global evaluation. Retrieved from: http://unesdoc.unesco.org/images/0001/000122/012286eb.pdf.

UNESCO. (2006a). Education for all global monitoring report, why literacy matters. Retrieved from: http://www.unesco.org/education/GMR2006/full/chapt5_eng.pdf.

UNESCO. (2006b). Education for all global monitoring report 2006, literacy for life. Retrieved from: https://reliefweb.int/sites/reliefweb.int/files/resources/141639e.pdf.

UNESCO. (2006c). Mapping the global literacy challenge. Retrieved from: http://www.unesco.org/education/GMR2006/full/chapt7_eng.pdf.

UNESCO. (2008). Functional adult literacy (FAL) programme country profile: Uganda. Retrieved from: http://www.unesco.org/uil/litbase/?menu=4\&programmeme=138.

UNESCO. (2013). Economic empowerment and functional adult literacy programme, country profile: Kenya. Retrieved from: http://litbase.uil.unesco.org/?menu=4\&programme $=145$.

UNESCO. (2015). Education 2030: Towards inclusive and equitable quality education and lifelong learning for all: World Education Forum. Retrived from: http://unesdoc.unesco.org/images/0024/002456/245656e.pdf.

UNESCO. (2016). Integrated community-based adult education (ICBAE), country profile: Tanzania. Retrieved from: http://litbase.uil.unesco.org/?menu=4\&programme=228.

UNESCO, E. (2006). Global monitoring report: Literacy for life. Paris: UNESCO.

Vágvölgyi, R., Coldea, A., Dresler, T., Schrader, J., \& Nuerk, H.-C. (2016). A review about functional illiteracy: Definition, cognitive, linguistic, and numerical aspects. Frontiers in Psychology, 7, 1617.Available at: https://doi.org/10.3389/fpsyg.2016.01617.

Wong, Y. N. (2012). World Development Report 2012: Gender equality and development. Paper presented at the The Forum for Development Studies. 